\title{
TERTULLIAN ON THE TRINITY
}

\author{
BRYAN M. LITFIN*
}

Moody Bible Institute, Chicago

\begin{abstract}
Tertullian is often portrayed as a prescient figure who accurately anticipated the Nicene consensus about the Trinity. But when he is examined against the background of his immediate predecessors, he falls into place as a typical second-century Logos theologian. He drew especially from Theophilus of Antioch, Justin Martyr, and Irenaeus of Lyons. At the same time, Tertullian did introduce some important innovations. His trinitarian language of 'substance' and 'person', rooted in Stoic metaphysics, offered the church a new way to be monotheistic while retaining the full deity and consubstantiality of the Word. Tertullian also significantly developed the concept of a divine oikonomia, God's plan to create and redeem the world. The Son and Spirit are emissaries of the Father's will—not ontologically inferior to him, yet ranked lower in the way that the sent are always subordinate to the sender. For this reason, Tertullian denied that a Father/Son relationship was eternal within the Trinity, seeing it rather as a new development emerging from God's plan to make the world. Such temporal paternity and filiation distances Tertullian from the eventual Nicene consensus, which accepted instead the eternal generation theory of Origen. While Tertullian did propose some important terms that would gain traction among the Nicene fathers, he was also marked by a subordinationist tendency that had affinities with Arianism. Tertullian's most accurate anticipation of Nicaea was his insistence on three co-eternal and consubstantial Persons. Historical theologians need to start admitting that Tertullian was a far cry from being fully Nicene. Rather, he offered a clever but still imperfect half-step toward what would become official orthodoxy..
\end{abstract}

KEYWORDS: Trinity, Praxeas, substance, person, logos

The English word 'Trinity' comes from the Latin trinitas, a noun denoting a triad or an entity with a threefold structure. The first Christian known to have used this word with reference to the biblical God was Tertullian of Carthage. If for no other reason than this, he would be important in the history of doctrine, but Tertullian gives us plenty of other reasons to appreciate him as well. The great apologist not only bequeathed us the term 'Trinity', he also offered a formula that, more than a century later, would assume the status of doctrinal orthodoxy. God is unam substantiam in tribus cohaerentibus, 'one substance cohering in three' (Tertullian 1954: 12.7). And 
when it comes to those 'three', Tertullian consistently refers to them as distinct personae. Therefore his theology is not far-in terms of wording, at least-from what the Council of Nicaea would decree to be true of God in the year AD 325. The Nicene Creed's language gained widespread acceptance before the century was out, and it has not been formally contested ever since. Tertullian's seemingly accurate anticipation of future orthodoxy has assured him a central place in modern treatments of historical theology.

To drive home the significance of the point, let us consider some examples. In a widely used textbook, Roger Olson writes, 'It is not too much of an exaggeration to say that Tertullian seems to have already settled [the doctrines of the Trinity and christology] hundreds of years before the rest of the church settled them, and if later church leaders and theologians had only listened more carefully to Tertullian, many theological disputes and controversies could have been avoided' (1999: 95). In other words, a lone figure had discovered in AD 200 what it took the rest of the church another century and a quarter to determine! This is high praise indeed for Tertullian's accomplishments.

Many other modern interpreters, even if not as enthusiastic as Olson, have come to similar conclusions about the substantial accuracy of Tertullian's reflections on the Trinity. Franz Dünzl remarks that Tertullian 'presented the first sketch of a theology of the Trinity which is really worthy of the name' (2007: 30). Gregg Allison's Historical Theology, intended as the historical companion volume to Wayne Grudem's popular systematics textbook, argues that 'Tertullian's wording became the foundation for the church's definition of the Trinity' (2011: 237). Alister McGrath claims that 'Tertullian gave the theology of the Trinity its distinctive vocabulary' (1998: 62). Stephen Holmes says Tertullian's work is 'of enormous significance in Latin trinitarian theology, not least in introducing virtually all the technical terminology that would become standard' (2012: 69-70). Even the French Jesuit scholar Joseph Moingt, who turned his doctoral thesis into a fourvolume work on Tertullian's view of the Trinity in 1966, could write that, 'Tertullian's work Against Praxeas is, strictly speaking, the first treatise of Trinitarian theology' in the ancient church (1966: 53, translation mine).

Why such enthusiasm for Tertullian's trinitarianism? As the above selections demonstrate, the answer is essentially terminological. Historical theologians like to suggest that Tertullian's use of the term trinitas, and his one substantia/three personae formula, make him a kind of proto-Nicene hero. He is viewed as having 'gotten it right' ahead of time-a sort of Athanasius of the third century. But how Nicene was Tertullian? Can he rightly be called, as Marian Hillar would have it, the 'originator of the Trinity' (2012: 190220)? Or did his doctrine fall short of later trinitarian standards-and if so, in what ways? Despite the high praise he often receives, it is worth asking 
whether Tertullian's views in the third century cohered with what would become the normative doctrinal standard in the fourth. To what degree did Tertullian anticipate the Nicene consensus?

A three-step approach will be used to answer this question. First, we will take a brief look at the contours of the Nicene and 'Arian' views of the Godhead in the early fourth century. (Admittedly, the term 'Arian' is simplistic; yet it is the most convenient way to designate all the theological outlooks which deny the full consubstantiality of the Son with the Father.) This overview will serve as a baseline by which to evaluate Tertullian's conformity with 'orthodoxy'. Second, we will investigate where Tertullian may have gotten his views. An assessment of his most influential predecessors will help us determine in what ways he was a new and innovative thinker who truly advanced the trinitarian discussion. Finally, we will examine what Tertullian actually believed about the Trinity. The primary work in which he lays out his theology is Against Praxeas. Therefore, we will tease out the basic thesis of this work, focusing on its early chapters where the author states his position succinctly (rather than delving into his later use of scripture to back up his arguments). In the end, having laid out the evidence, the present article will offer some analysis of Tertullian's trinitarian views in light of later orthodox formulations.

\section{The Nicene Standard in the Early Fourth Century}

In the year AD 318, Arius, a popular presbyter at Alexandria, challenged his bishop Alexander over the issue of the Son's co-eternality with the Father. Of particular concern were Alexander's robust claims about the unity of the Trinity, which sounded to Arius like Sabellianism-the ontological equivalence of the Father and Son. To properly differentiate the divine Persons, Arius claimed the Son's existence was derived from the Father's, and before that, the Son did not exist (Socrates Scholasticus 1995: 3). This meant the Son must be a created and non-eternal being, while God the Father alone is eternally existent.

The various ideas that came to bear the name 'Arianism' were all predicated on a rarified view of true and fullest deity. Drawing from Platonic idealism, Arius and like-minded theologians insisted that for God to be God, he had to be utterly transcendent and separate from the world. And yet, according to the bible, God is the Creator. How can such a remote God be in contact with the physical cosmos to carry out the work of creation and providential stewardship? In his innermost essence, he cannot. Therefore, he must have brought forth some kind of principle from within himself to do the job-an entity capable of mediating between a distant God and his physical handiwork. This entity is called the Logos. Such ideas were not new to Arius. They were common enough in Middle Platonism, which had 
borrowed heavily from Stoicism. The concept of an intermediate Logos was then channeled into the catholic church through the Jewish philosopher Philo of Alexandria. Arius had incorporated such commonplace ideas into his theology and was following them to their logical conclusion. The true God, being utterly transcendent, required a mediating principle. If this is so, the intermediary, while possessing a certain kind of deity, must be reduced in degree or status from the sovereign God who is at work through him.

The Arians took quite literally the proclamation of Jesus that 'The Father is greater than I' (John 14:28). This should not be understood to mean the Son is inferior to humans, nor any other earthly creation. Arius always insisted Christ was highly exalted and uniquely glorified among all creatures. Nevertheless, he was part of the created order. He came about by the decree of the Father; and prior to the act of divine will that brought him into being, he did not exist. Khaled Anatolios sums up the basic contours of this theology when he notes that Arius possessed

an unflagging insistence on the utter singularity of the one unoriginated and Unbegotten God. Thus, while we can speak of a divine Trinity, only the first entity (hypostasis) is truly and fully God. The unity of this Trinity, composed of unequal hypostaseis, is a unity of will rather than of substance. This doctrine does not deny the Son's divinity but presumes the framework of a graded hierarchy of transcendence in which it is possible to speak of variation in degree within the divine realm... [The Son's] generation from the Father is thus the first and highest instance of creaturehood (Anatolios 2011: 17).

In other words, an 'unequal' and non-substantial unity within the Godhead is the core idea of the Arian view.

The primary figure associated with the 'orthodox' response to the perceived threat of Arianism was, of course, Athanasius. This precocious young deacon followed Alexander as bishop of Alexandria around AD 326. One of the primary goals of Athanasius' ministry was to defend the Creed of Nicaea, at least as he interpreted it. The creed's central statement was its affirmation that the Son is homoousion to patri, 'consubstantial with the Father'. In the context of Nicaea, the term ousia (substance) was intended to safeguard co-eternality of the Persons and prevent any ontological subordination within the Trinity. If the Father and Son were said to share the same substance, both must be eternally existent and equal in their divinity, even if they possessed distinct roles of commanding and obeying.

During the ensuing decades after the council, different theological camps arose, each centered on the way it wished to speak about ousia. Only the Nicene party embraced the homoousios formula, while the various 'Arians'-always hearing Sabellianism behind such terminology-attempted to 
distinguish the essence of the Father from that of the Son. As we have already seen, this meant the essence of the Son must be derived, temporal, and contingent, and therefore inferior to the Father's essence in important ways.

To defend themselves against charges of Sabellianism, the Nicenes developed not just the language of three prosopa, or 'roles' within the Trinity, but three hypostaseis, or distinct personalities. This approach proved problematic to Latin speakers like Jerome, for the Greek word hypostasis was equivalent to the Latin substantia, since both meant 'to stand under or among', that is, 'to be existent'. Such language suggested three distinct existences within the Godhead, and this sounded to nervous Christian ears like tritheism. Over time, though, the intent of the terminology was clarified. The basic distinction was this: the Nicenes taught three separate personalities who shared a single divine substance, while the so-called Arian factions held that the substance of the Son lacked the Father's eternality, and so was a created substance, notably inferior in its essential qualities. Thus we can see that the homoousios formula became the dividing line between the two camps.

One of the most important entailments of the Nicene party's insistence on consubstantiality and tri-personality within the Trinity was the implication that an eternal love relationship has always been shared by the members of the Godhead. Each Person of the Trinity, precisely because he is a fully divine Person, is therefore a lover and a beloved. However, in the initial stages of the controversy, the Holy Spirit was not really in view. Practically speaking, what mattered most in AD 325 was the bi-personality of the first two Persons as they related to each other as Father and Son. For the Nicene church fathers, the eternal Logos was not just abstract 'reason' in the Divine Mind, but Logos tou patros, the Father's own Word. Athanasius writes that the Son

is absolute wisdom, very Word, and himself the Father's own power, absolute light, absolute truth, absolute justice, absolute virtue, and indeed, stamp, effulgence, and image. In short, he is the supremely perfect issue of the Father, and is alone Son, the express image of the Father... So of necessity, the Word is in his begetter, and the begotten coexists eternally with the Father (Athanasius 1971: 131, italics mine).

Here we discern how important it was in Nicene theology for the Father and Son (and later, the Spirit) to be intimately related to one another-to be 'in' and 'with' one another. Each Person of the Trinity participates equally in the divine goodness, and it has always and forever been this way.

In contrast, Arian theology emphasized the distance between the first and second Persons (though never denying the terminology of paternity 
and filiation). The Son was related to the Father because the Father willed this connection into being-not because the two are eternally and inextricably bound together in the unity of their shared essence. This meant that the Son, as a creature, could not perfectly know or comprehend the Father. The Arian view stood in sharp distinction to that of the Nicenes, for whom consubstantiality entailed the intimate and perfect co-knowing of the trinitarian Persons. Eventually this familiar knowledge-which is actually a form of self-knowledge-would come to be described in the Eastern tradition as perichoresis, or 'interpenetration'.

So then, the Nicenes held to an eternal and intimate equality of the Persons within the Godhead, while the Arians denied their consubstantiality and tended to separate or gradate the Three. Having now laid out the basic contours of the two theologies, it is time to determine how Tertullian measured up to later standards. To do this, we must first ask, where did Tertullian get his views?

\section{Tertullian's Predecessors on the Trinity}

The ancient Carthaginian church father would have been the first to say (as in fact he did say on numerous occasions) that he stood in continuity with the faith handed down through the ages. Two strands of prior theological reflection on the Trinity quickly become apparent in Tertullian's thought. The first was the so-called 'Logos theology' held by the second-century apologists who employed Greek metaphysical categories to defend the Christian faith. Although Tertullian borrowed from them freely, he also drew from a second influence: Irenaeus of Lyon, who ministered in the generation just before Tertullian's active period. Irenaeus was much less speculative than the Logos theologians-perhaps because that was his personality, or perhaps because his main theological goal was to refute heretics on biblical and ecclesial grounds rather than philosophical. Tertullian liked that approach too, and indeed he perfected it in his own apologetic efforts. Yet Tertullian could also make use of Logos theology like the Greek apologists did. Therefore, we must investigate both of these influences on Tertullian if we are to understand his trinitarianism.

Let us turn our attention first to Theophilus of Antioch, who wrote an apologetic work in three volumes that Tertullian appears to have read. In the second volume, Theophilus states that God's Logos

always exists, residing within the heart of God. For before anything came into being, God had him as a counselor, being his own mind and thought. But when God wished to make all that he determined, he begot this Word, uttered, the first-born of all creation, not himself being emptied of the Logos, but having begotten Logos, and always conversing with his Logos... The Word, then, is God, and is naturally produced from God. Whenever the Father of the universe wills, 
he sends him to any place; and the Logos, coming, is both heard and seen, being sent by God, and is found in a [specific] place (Theophilus of Antioch 1994: 103).

Notice that Theophilus posits an eternal existence for the Word. God always converses with this Logos, who is described as 'God', and yet is 'naturally produced' from God. Only at a later point is the Logos 'begotten'; that is, he becomes a Son when God decides to embark on his work of creation. The Logos who is now begotten as a Son is 'sent' by God to carry out the divine will.

Theophilus borrows an important term from Stoic philosophy to express this concept of sending. When he says the Son was 'uttered', he uses the Greek word prophorikos, a technical philosophical term that stands in contrast to endiathetos, or 'internal'. Just as a spoken word is formed internally in our minds before we utter it, so God's Logos remained within him until it was time to speak the Word forth in the act of begetting a Son. Theophilus writes,

God, then, having his own Word internal within his own bowels, begat him, emitting him along with his own wisdom before all things. He had this Word as a helper in the things that were created by him, and by him he made all things (1994: 98).

The word 'internal' here is endiathetos, which clearly indicates a kind of immanent existence within God's mind. God reasons with his Word as a discourse partner; but when it is time to create, God begets him and 'emits' him so he can function as a 'helper'. All of these ideas will be expressed in Tertullian's trinitarian reflection as well.

Another important influence on Tertullian was Justin Martyr, who is considered the most significant of the second-century Greek apologists. Like the other Logos theologians, Justin attempted to grapple with the preexistence of Christ by describing him as the internal discourse partner in God's mind (2003: 96). The Word existed eternally with God in rational communion until the time was right for the Word to become a Son. Justin describes him as 'the Logos who is with God and is begotten before all creation, when in the beginning God created and set in order everything through Him' (1997: 77). He alone can be called Son, and Justin also allows him to be called 'Christ' at this point, for he was anointed by God in order to carry out the work of creation. As a man who became incarnate, the Logos/Christ/Son is known as 'Jesus', the Savior of humankind.

However, Justin frequently speaks of a stage between the divine works of creation and incarnation. One of his most prominent uses of the term logos was his notion of the 'spermatic Word'. Justin believed seeds of the Logos were dispersed among humans prior to the coming of Jesus Christ. The 
Logos was active among Jews and pagans alike, using the Old Testament writings and divine theophanies in the case of the Jews, and the reasonable deductions of the philosophers in the case of the Greeks, to offer wisdom from the one true God. Justin writes,

For each person [in pre-Christian history] spoke well, according to the part present in him of the divine Logos, [who is] the Sower... Therefore, whatever things were rightly said among all people are the property of us Christians. For next to God, we worship and love the Logos who is from the unbegotten and ineffable God, since also He became man for our sakes, that, becoming a partaker of our sufferings, He might also bring us healing (1997: 84).

We can discern in a statement like this Justin's commitment to a great, unfolding plan of God. The Logos was active in pre-Christian ages, bringing people to a preliminary knowledge of himself until the time arrived for the Logos to assume flesh to effect salvation. For this reason, Christians worship and love the Logos 'next to' the unbegotten and ineffable God who sent him. Although Tertullian does not make much use of Justin's 'spermatic' idea, he clearly believed the Word was active prior to his incarnation as part of God's cosmic plan for the world. And just as we saw with Theophilus, so we discover here that sonship is not eternal within God. Instead, the Word's begetting as a Son is a new development in the implementation of the divine plan.

Although Tertullian is rightly compared to the Logos theologians, he possessed one great advantage over them: he had fully incorporated the theological insights of Irenaeus of Lyon. Like the Greek apologists, Irenaeus deployed a full-fledged theology of the Word. However, Irenaeus added a theological dimension that would prove beneficial to Tertullian: he had made the biblical word oikonomia central to his thought. The concept of a divine 'economy' was not unknown, of course, prior to Irenaeus. This term had been used by the apostolic fathers and apologists alike. Yet none of them employed it in the sense of a great, unfolding plan the way Irenaeus did. Eric Osborn, who has extensively studied the concept of 'economy' in Irenaeus, summarizes it as follows:

God makes, man is made. As wise architect and sovereign king, God creates from nothing all that is, ordering opposites by his artistry. His plan unites disparate elements from creation to Christ (2001: 49; cf. 51-94).

The twin illustrations of a master-builder and a monarch are drawn from Irenaeus himself (Irenaeus 1994: 370). Osborn notes that there is no good English translation for oikonomia, but that it means something like a system or a plan (2001: 75). The term has connections to ancient architectural 
methods, by which a building is constructed piece-by-piece to form a fitting whole. The entire project is well-disposed and methodically laid out as the architect carefully moves toward his intended outcome.

Yet this architect does not just draw up the blueprints; he also hammers the nails and lays the roof-tiles himself. In this vein, Irenaeus spoke of God's Word and Spirit as his two 'hands' (1994: 463, 531). They are the instrumental means by which the builder's will is carried out. Whether through the image of an architect unfolding his master-plan, or a king extending his rule over an empire through designated proxies, Irenaeus presented his readers with a cosmic view of creation, incarnation, and redemption. The bishop of Lyon understood that God was deploying a single, grand economy through its distinct and proper stages. Irenaeus clearly expanded the scale of Christian reflection on the salvific plans of God. Now all that remained was for Tertullian to gather up these ideas and locate them within God's own intra-trinitarian life.

\section{Tertullian's View: 'Economic Trinitarianism'}

The treatise Against Praxeas is widely recognized as Tertullian's greatest work on the Trinity. The view apparently taught by Praxeas has come to be called 'modalism', thanks to that designation appearing in Adolf von Harnack's History of Dogma (1897: 51ff). ${ }^{1}$ Tertullian simply calls his opponent a 'monarchian' (1948: 141). This ‘monarchian' view was an attempt to retain a strict type of monotheism for the Christian faith. It accomplished this goal by suggesting the Father and Son were different expressions of the same being, without any personal distinctions between them. In other words, the Father is himself the Son, and therefore experiences the Son's human frailties. Shortly after Tertullian's day, a theologian named Sabellius gave this idea a more triadic pattern by incorporating the Holy Spirit into the schema. Sabellius argued for a historical sequence in which the Father, Son and Spirit functioned as progressive 'dilations' of the one God for the purposes of creation, redemption, and inspiration. But Tertullian himself betrays no knowledge of this idea. His efforts were directed against a view whose chief error was to conflate the Father and Son, meaning that, among other things, the Father suffered on the Cross - a view known as 'patripassianism', which Tertullian found abhorrent. He thought modalism was a doctrine held only by heretics with poor exegesis who could not see that holy scripture presents the Father and Son as distinct interlocutors.

1 Praxeas may have been the Roman deacon Callistus, supervisor of the catacombs that still bear his name today (Brent 1995: 525-535). Callistus went on to become the bishop of Rome. 
Yet modalism was not just the doctrine of educated heretics; it also seems to have been widespread among the simplices, the 'simple folk' in the church at large. This group did not draw Tertullian's ire the way the archheretics did, for they held to the church's traditional doctrine in innocent, genuine faith. Nevertheless, while Tertullian hesitated to disparage them as 'thoughtless and ignorant' for their pronounced monarchian tendency, he felt the need to correct these average Christians, whom he considered to be the 'majority' of believers (1948: 132). Over time, as Tertullian moved further into Montanism, he associated the simple folk with the less spiritual 'catholics' who had not embraced the New Prophecy. It seems quite possible, then, that the bulk of Carthaginian Christians around the turn of the third century-and perhaps also those at Rome under popes like Zephyrinus and Callistus - had adopted something much closer to a monarchian view than a trinitarian one (McGowan 2006: 449-451). This is significant. Tertullian was not simply refuting fringe heretics in Against Praxeas, but trying to convince the average faithful Christian to embrace the notion of multiplicity alongside unity in the Godhead. To do this, Tertullian had to emphasize Irenaeus' catchword oikonomia, which means 'economy'.

Or does it? In patristic usage, oikonomia is notoriously difficult to translate. Etymologically the word derives from oikos, 'house', and nomos, 'law', 'custom', or 'habitual practice'. The assigned custom of the house was how the master ran the affairs of his estate, and from this usage oikonomia came to mean any kind of stewardship, arrangement, or disposition of affairs. The word is biblical, appearing once in Luke's Gospel and six times in the Pauline Epistles (Luke 16:2-4; 1 Corinthians 9:17; Ephesians 1:10 and 3:2, 9; Colossians 1:25; and 1 Timothy 1:4). Bauer's lexicon and TDNT concur in providing three main translations (Bauer 1979: 559-560; Kittel and Friedrich 1985: 679). The word can mean the office of one who administers, such as a household steward or an apostle; it can mean training in the true faith; and most significantly, it can mean God's divine plan or arrangement of affairs for the sake of salvation. This last usage was employed widely among the church fathers, who often used oikonomia as a synonym for the incarnation, or the age ushered in by the coming of Christ. Lampe's patristic lexicon lists numerous definitions along these lines, leaving the impression that oikonomia's semantic range ballooned during the first Christian centuries (1976: 940-43). For this reason, word studies alone will not solve anything. We must examine what Tertullian meant in context when he spoke of the 'economy'.

In his treatise Against Praxeas Tertullian used the term oikonomia (transliterated into Latin characters or perhaps borrowed straight from the Greek; the manuscript traditions differ) to describe God's cosmic plan to create and redeem. The best English translation would not be 'economy', 
which reminds the modern person of business systems and financial affairs. We should instead translate oikonomia as 'plan'. Tertullian believed the Trinity was a great plan unfolded for the sake of creation and redemption. At a certain juncture, God, while not ceasing to be what he always was, nonetheless extended himself or projected himself forward, so that the three Persons became more clearly distinguished. By means of these now-moredistinct Persons, the one God creates the world, rules over it, and enters into it for salvation. Like Theophilus of Antioch, Tertullian describes the earliest phase of intra-trinitarian life as a mental process in which God discourses with his Word; but then a new dimension of relationship is added when the Word becomes a Son; and another extension occurs when the Son takes on flesh to dwell among human beings. Furthermore, the Holy Spirit is an extension of the Godhead for the sake of creation and redemption alongside the Son, though Tertullian is less clear about the details of his pneumatology.

The word 'economy' appears early in Against Praxeas, and we must notice how the term is used. Tertullian affirms his belief in

one only God, yet subject to this dispensation (which is our word for economy) that the one only God has also a Son, his Word, who has proceeded from himself, by whom all things were made (1948: 131).

It is significant that Tertullian says God is 'subject to' (sub) a dispensation as part of his own essence. Tertullian does not simply say, as Irenaeus had before him, that God is carrying out a plan in salvation history, as seen especially in the incarnation. Rather, God's very self is to be understood as dispensed or arranged in an oikonomia. Thus, Tertullian makes the idea of a plan essential to the divine being.

The same point is made a little later when Tertullian writes about the 'mystery of the economy'. This mystery

disposes the unity into trinity (unitatem in trinitatem disponit), setting forth the Father and Son and Spirit as three, three however not in quality but in sequence, not in substance but in aspect, not in power but in [its] manifestation, yet of one substance and one quality and one power, seeing it is one God from whom these sequences and aspects and manifestations are reckoned out in the name of the Father and the Son and the Holy Spirit (1948: 132).

A few lines down, Tertullian addresses the monarchian simplices with the admonition that they must not shy away from multiplicity, but must believe in God 'along with his economy'. This way of speaking continues to give the impression that the economy is not only a plan that God is unfolding in history, but is a fundamental way his own being is 'disposed' or 'arranged'. 
What does this arrangement look like? At this point Tertullian begins to give illustrations. He first appeals to the concept of a monarch's imperial rule. Just because an emperor has proxies who carry out his will does not mean the single substance of his imperium is disturbed. So too, the Son and Spirit are administrators of the Father's will (1948: 132-34). Tertullian also provides three examples of natural phenomena that involve a kind of projection, yet without separation from the source (1948: 138-140). A root sends up a shoot which produces fruit; a spring bubbles into a river from which an irrigation canal is drawn; and the sun emits a ray which coalesces into a focal point. Each of these projections remains united to its source even as it is sent forth. Tertullian is aware that his language here sounds like some Gnostic schemes, but with his typical boldness, he claims he is simply taking back a term the heretics have wrongly borrowed. Tertullian did not intend to back down from a 'projection' model of God just because that word (probole) appeared in Gnostic sources. For Tertullian, the sending forth of emissaries is an inherent part of who God is. Scripture reveals him to be a God who has arranged himself according to an eternal plan.

The plan of God centered especially on the work of the eternal Logos. Tertullian shows himself to be squarely in line with the Greek apologists in his discussion of the Logos who became a Son for the sake of creation and redemption (1948: 134-138). Tertullian's Latin words for the Logos are ratio or 'reason', sermo or 'word, discourse' (this term is used more often than verbum), and sophia or 'wisdom'. The divine being who goes by these names conversed with God in eternity past. Then, at the right time, the sermo of God was 'begotten for activity' - the activity of creation when God said, 'Let there be light'. It is at this point that the sermo becomes a Filius, a 'Son'. In so doing, he causes the one God to become a Father (1948: 137). This idea is not original to Tertullian. He is simply following the line of thought pioneered by Theophilus of Antioch, Justin Martyr, and other apologists.

Yet Tertullian does have some unique contributions to make. In order to balance unity and diversity within the Godhead, he introduced the innovative terminology of substantia and persona into the history of trinitarian discourse. In so doing, Tertullian appears to have been drawing from Stoic metaphysics. The Stoics believed in four distinct categories of existence: substance, quality, disposition, and relative disposition (Rist 1969: 152-172).

Tertullian's pair of Latin terms basically reduces the four to two. In Stoicism, 'substance' defines what a thing is. This substance always includes innate 'qualities', that is, the essential attributes of the substance being described. Therefore, the term substantia as Tertullian used it signified the existence of a single, discrete entity (here, the One God), along with the qualities inherent to that entity (such as love, goodness, etc.). This framework allows for the full deity of the Logos. To say that Jesus Christ is divine in his 
'substance' is to say that he has all the qualities attributable to what we call 'God'.

Now if Tertullian had stopped there, he would have been a modalist. He would have had no way to prevent the collapse of Father and Son into a single being, one whose paternity and filiation are illusions arising only from being viewed from different angles. The term persona, then, was employed by our author to differentiate the three members of the Trinity by describing their interpersonal relations (Rankin 2001: 29-34).

This corresponds to the Stoic concepts of 'disposition', or the particular way a thing exists as we humans encounter it; and 'relative disposition', which describes a thing in relationship to other things. These terms were the epistemological means by which a given object could be distinguished from another-the apple in your hand as opposed to one hanging on a tree or sitting in a basket (Rist 1969: 167-172).

When talking about God, we use the term 'person' to distinguish the three ways that God comes to us (for the Persons do not all have the same relationship to us); and this term also implies that there are distinct ways that the Persons relate to each other.

So, in Tertullian's new trinitarian schema, God is characterized by a single divine 'substance' of rulership over the cosmos. Yet he is fundamentally arranged or disposed in three personae. One of these Persons possesses rulership intrinsically, while the two others have it derivatively; and these two are sent forth to mediate the unified rulership of the whole to the world.

Although the two emissaries share the substance and quality of divine power, their personal distinctness comes from being sent ones, or mediators, or obedient missionaries. The Son and Spirit have no less power or status than the Father, yet they are arranged or disposed at a lower gradefor the sent are always lesser, in a certain sense, than he who sends them on their missions.

The outward manifestation of their power is therefore different from that of the Father. Tertullian is borrowing Stoic terminology here to emphasize the unity of the divine substance while distinguishing three Persons who are differentiated by their respective tasks. The Persons inevitably come to us in a graded hierarchy by which the Father sends the Son and the Son sends the Spirit. This ranked or tiered disposition is inherent in God's own being.

\section{Evaluation of Tertullian's 'Orthodoxy'}

As we consider Tertullian's impact on trinitarian discourse, let us first summarize our findings in a chart that compares and contrasts the various views: 


\begin{tabular}{|l|l|l|}
\hline Nicene View & Arian View & Tertullian's View \\
\hline $\begin{array}{l}\text { Father and Son are co- } \\
\text { eternal }\end{array}$ & $\begin{array}{l}\text { God is eternal, Son is creat- } \\
\text { ed later }\end{array}$ & $\begin{array}{l}\text { The Persons of the God- } \\
\text { head are eternal, but a } \\
\text { Sonship relationship is a } \\
\text { later (temporal) creation }\end{array}$ \\
\hline $\begin{array}{l}\text { The Son, though a Me- } \\
\text { diator, is ontologically } \\
\text { equal to the Father }\end{array}$ & $\begin{array}{l}\text { The Son, as a Mediator, is } \\
\text { at a lower grade than the } \\
\text { Father }\end{array}$ & $\begin{array}{l}\text { The Son's power and } \\
\text { status are equal to the } \\
\text { Father's, but the Father } \\
\text { has arranged or disposed } \\
\text { the Son into a lower rank } \\
\text { or grade }\end{array}$ \\
\hline $\begin{array}{l}\text { The Father and Son are } \\
\text { equal in divinity }\end{array}$ & $\begin{array}{l}\text { The Father is superior to } \\
\text { the Son in divinity }\end{array}$ & $\begin{array}{l}\text { The Father and Son are } \\
\text { equal in divinity }\end{array}$ \\
\hline $\begin{array}{l}\text { Existence of the Son is } \\
\text { due to his inherent unity } \\
\text { with the Father }\end{array}$ & $\begin{array}{l}\text { Existence of the Son occurs } \\
\text { by a decision of the Father }\end{array}$ & $\begin{array}{l}\text { Role of Sonship occurs by } \\
\text { the decision of the Fa- } \\
\text { ther, but the Person him- } \\
\text { self eternally exists }\end{array}$ \\
\hline $\begin{array}{l}\text { The Son is consubstan- } \\
\text { tial with the Father }\end{array}$ & $\begin{array}{l}\text { The Son does not share } \\
\text { fully in the Father's sub- } \\
\text { stance }\end{array}$ & $\begin{array}{l}\text { The Son is consubstantial } \\
\text { with the Father }\end{array}$ \\
\hline $\begin{array}{l}\text { The single divine sub- } \\
\text { stance entails the equali- } \\
\text { ty of the three Persons } \\
\text { loving unity with the Son } \\
\text { stances create a ranking of } \\
\text { the Persons }\end{array}$ & $\begin{array}{l}\text { Divine Fatherhood creates } \\
\text { less divine Son }\end{array}$ & $\begin{array}{l}\text { Single substance entails } \\
\text { ontological equality, but } \\
\text { divine 'economy' necessi- } \\
\text { tates ranking of the Per- } \\
\text { sons }\end{array}$ \\
$\begin{array}{l}\text { Fatherhood and Sonship } \\
\text { are not intrinsic to the } \\
\text { Trinity; therefore, some } \\
\text { relational distance is im- } \\
\text { plied }\end{array}$ \\
\hline
\end{tabular}

So now we may ask: Did Tertullian anticipate the fourth-century, orthodox perspective of consubstantiality and the full deity of the Son? Or did he subjugate the Son as a created being? In other words, was he pre-Nicene or pre-Arian? Despite the fact that many historical theologians have wanted to name Tertullian as a great forerunner of Athanasius and the Cappadocians, in reality it would be more accurate to say he stood halfway between the Nicene and Arian positions. And we must also point out that both of those views had roots in certain ideas found in the Logos theology. For example, both camps agreed on the necessity of a mediator between the Father God and the world. Tertullian was not really a forward-thinking Nicene trinitarian born a century out of time, but a typical theologian of his day who was repeating many commonplaces received from the second century-points about which the Arians and Nicenes would concur. Therefore, we should 
not be too quick to anoint Tertullian as the Latin foundation upon which the Greek edifice of Nicaea was going to be built.

Like the Arians and the Nicenes, Tertullian had received a traditional anti-pagan monotheism that he had no desire to overturn. Though he had nothing positive to say about his opponent Praxeas, he nonetheless validated the monarchian instinct when he attributed it to the simplices, the good, common folk who made up the bulk of the catholic church. Christians of all types (the Marcionites excepted) knew they were monotheists like the Jews, not polytheists like the Greeks. In affirming the great Hebraic acclamation that the Lord our God is one, Tertullian was no different from either the Nicenes or the Arians. The question under dispute in the fourth century was not whether but how the worship of Jesus should be incorporated into a monotheistic framework.

Tertullian was most like the Nicene camp in his insistence on the coeternality of the three Persons of the Trinity and the full equality of their divinity. Without question, Tertullian's clear and unequivocal use of the terms 'substance' and 'person' are important contributions in the history of doctrine. Although the Son and the Spirit are said to be 'conjoint of the Father's substance' (1948: 133), even so, God's Logos is clearly 'another beside himself', and is 'established [by God] as a second person', while the Spirit occupies the 'third place' (1948: 136, 133). Tertullian sums up his view, 'Whatever therefore the substance of the Word was, that I call a Person, and for it I claim the name of Son: and while I acknowledge him as Son, I maintain he is another beside the Father' (1948: 138). In other words, while the Son does share the substance of the Father, both are distinct Persons. This is precisely the trinitarian terminology that would eventually win the day. Many decades later, Gregory of Nyssa could write, 'We therefore affirm that while they share ousia in common, there are characteristics to be seen in the Trinity which are incompatible and not held in common; these constitute the particular character of the persons (prosōpa) of whom the faith has taught us' (1975: 34).

Yet while Tertullian was proto-Nicene in certain fundamental ways, he often sounded a lot like the Arians as well. For example, he tended toward a profound theological subordination of the Son and the Spirit. Although this was not a temporal subordination in which the Persons lacked eternal existence, nor an ontological subordination in which they suffered essential shortcomings, Tertullian nevertheless arranged the Three in a kind of selfagreed hierarchy. The Trinity, he believed, possessed a genuine, stepwise ranking according to each Person's gradus, forma, and species. This is indeed a bold view of the architecture of the Trinity, one that skirts close to Arian subordinationism. 
But even more problematic from an orthodox point of view was Tertullian's firm conviction that a relationship of fatherhood and sonship is not intrinsic to the Trinity. Such teaching would not have been countenanced by any card-carrying Nicene theologian in the fourth century. Thanks to Origen's introduction of a robust doctrine of eternal generation into the theological stream, the notion that the First Person was not essentially and eternally a Father, or that the Trinity was not itself constituted by the shared love of the Father and Son in the Spirit, became anathema to later generations. Yet this was precisely what Tertullian believed, and for this reason his doctrine of temporal paternity and filiation was closer to the Arian point of view.

What can we say about Tertullian's theological emphasis on the divine 'economy' - that God has chosen to arrange himself as an orderly plan by which he extends himself into the world for human and cosmic salvation? This notion is somewhat hard to pin down as having foreshadowed either the victorious theology or the heretical, since it was not really part of the classic trinitarian conversation. But let us take a closer look.

It is now recognized that the fourth century debates over the Trinity cannot be artificially bracketed from discussions about soteriology. Whose soteriological vision, then, would Tertullian have been aligned with-the Arians' or the Nicenes'? We have already noted that Tertullian's economic concept has roots in Irenaeus' thought; and there is a well-known connection between the atonement theology of Irenaeus and Athanasius. When we recall that oikonomia became a virtual synonym for the incarnation (Lampe 1976: 941-942), we are reminded of the kind of theology found in Athanasius' De Incarnatione, in which God encounters a divine dilemma due to human sin, and resolves to rescue his creatures by the Word's incarnation, passion, and resurrection. That is, human salvation hinges on a divine plan of incarnation: the steadfast intent of God to come down and save. Even when we acknowledge that real soteriological concerns motivated the Arians, too (as has been clear ever since Gregg and Groh pointed it out in 1981), we must still conclude that Tertullian's soteriological vision was closer to the Irenaean and Athanasian view of a Savior who bore our sins in his body on the tree, rescuing us from the Adamic fall, than with the Arian view of Christ as an exemplary model of virtue and perfect creaturehood. So in this respect, Tertullian's economic outlook seems to align more with the Nicene tradition than the Arian.

\section{Conclusion}

Historical theologians need to start admitting that Tertullian was a far cry from being entirely Nicene. The full-fledged set of ideas that we associate with Athanasius, the Cappadocians, and the creed of 325, much less of 381, 
awaited another century or two of development. Tertullian was instead a typical second-century theologian. His ideas were essentially those of the Greek Logos theologians combined with insights from Bishop Irenaeus. At the same time, we should recognize that Tertullian was a fertile and imaginative thinker, as well as a master of Latin wordplay and verbal nuances. Therefore, his quick and energetic mind-always enlivened by the challenge of a heretical enemy-has bequeathed to church history some important and long-lasting terminological innovations in the advancement of trinitarian doctrine.

Tertullian was a man of his own time, and this is a good thing; for if he had laid out his ideas at Nicaea in 325, he would have needed a lot of tutoring-along with a humble willingness to change!-to fall in line with the victorious council fathers. Anyone who knows Tertullian knows that humility and meekness were not his strengths. Better, then, to leave him in his own age and recognize him as having offered a clever but still imperfect half-step toward what would become Nicene orthodoxy.

\section{Bibliography}

Allison GR (2011) Historical Theology: An Introduction to Christian Doctrine. Grand Rapids, MI: Zondervan.

Anatolios K (2011) Retrieving Nicaea: The Development and Meaning of Christian Doctrine. Grand Rapids, MI: Baker Academic.

Athanasius (1971) Against the Nations. In Thomson RW (ed) Athanasius: Contra Gentes and De Incarnatione. Oxford: Clarendon Press.

Bauer W, Gingrich FW, and Danker FW (1979) A Greek-English Lexicon of the New Testament and Other Early Christian Literature. 2nd edition. Chicago, IL: University of Chicago Press.

Brent A (1995) Hippolytus and the Roman Church in the Third Century: Communities in Tension before the Emergence of a Monarch Bishop (Supplements to Vigiliae Christianae 31). Leiden: Brill.

Dünzl F (2007) A Brief History of the Doctrine of the Trinity in the Early Church, Bowden J (trans). London: T\&T Clark.

Gregg RC and Groh DE (1981) Early Arianism: A View of Salvation. Philadelphia, PA: Fortress.

Gregory of Nyssa (1975) On the Difference between Ousia and Hypostasis. In Wiles M and Santer M (eds) Documents in Early Christian Thought. Cambridge: Cambridge University Press.

Harnack A von (1897) History of Dogma, Buchanan N (trans), volume 3 (Theological Translation Library). Boston, MA: Roberts Brothers.

Hillar M (2012) From Logos to Trinity: The Evolution of Religious Beliefs from Pythagoras to Tertullian. Cambridge: Cambridge University Press. 
Holmes SR (2012) The Quest for the Trinity: The Doctrine of God in Scripture, History and Modernity. Downers Grove, IL: InterVarsity.

Irenaeus (1994) Against Heresies. In Roberts A and Donaldson J (eds) The Ante-Nicene Fathers, volume 1. Peabody, MA: Hendrickson.

Justin Martyr (1997) Second Apology. In Barnard LW (ed) St. Justin Martyr: The First and Second Apologies (Ancient Christian Writers 56). New York, NY: Paulist.

Justin Martyr (2003) Dialogue with Trypho. In Falls TB (ed) St. Justin Martyr: Dialogue with Trypho (revised Halton T and Slusser M). Washington, DC: Catholic University of America Press.

Kittel G and Friedrich G (1985) Theological Dictionary of the New Testament. Bromiley G (ed). Grand Rapids, MI: Eerdmans.

Lampe GWH (1976) A Patristic Greek Lexicon. Oxford: Clarendon.

McGowan A (2006) Tertullian and the 'Heretical' Origins of the 'Orthodox' Trinity. Journal of Early Christian Studies 14(4): 437-457.

McGrath A (1998) Historical Theology: An Introduction to the History of Christian Thought. Oxford: Blackwell.

Moingt J (1966) Théologie trinitaire de Tertullien, volume 1 (Théologie 68). Paris: Aubier.

Osborn E (2001) Irenaeus of Lyons. Cambridge: Cambridge University Press.

Olson RE (1999) The Story of Christian Theology: Twenty Centuries of Tradition E Reform. Downers Grove, IL: InterVarsity.

Rankin D (2001) Tertullian's Vocabulary of the Divine 'Individuals' in adversus Praxean. Sacris Erudiri 40(*): 5-46.

Rist J (1969) Stoic Philosophy. Cambridge: Cambridge University Press.

Socrates Scholasticus (1995) Church History. In Schaff P and Wace H (eds) Nicene and Post-Nicene Fathers, volume 2. Peabody, MA: Hendrickson.

Tertullian (1948) Against Praxeas. In Evans E (ed) Tertullian's Treatise Against Praxeas. London: SPCK.

Tertullian (1954) Against Praxeas. In Kroymann A and Evans E (eds) Tertulliani Opera: Opera Montanistica (Corpus Christianorum, Series Latina 2). Turnhout: Brepols.

Theophilus of Antioch (1994) To Autolycus. In Roberts A and Donaldson J (eds) The Ante-Nicene Fathers, volume 2. Peabody, MA: Hendrickson. 